\title{
Potassium and Phosphorus Fertilization Impacts on Bermudagrass and Limpograss Herbage Accumulation, Nutritive Value, and Persistence
}

\author{
Maria L. Silveira, ${ }^{\star}$ Joao M. B. Vendramini, Hiran M. S. da Silva, Bernardo M. M. N. Borges,
} Victor S. Ribeirinho, Julian J. J. Lacerda, Mariana V. Azenha, Pedro R. A. Viegas, and Andre D. Aguiar

\begin{abstract}
Despite scientific evidence suggesting that warm-season grasses can respond favorably to $K$ and $P$ fertilization, the increasing costs of fertilizers limit the extent to which these nutrients are used in pastures and hayfields. Two field studies evaluated 'Jiggs' bermudagrass [Cynondon dactylon (L.) Pers.] and 'Floralta' limpograss (Hemarthria altissima Stapf. and Hubbard) herbage accumulation (HA), nutritive value, and persistence to reduced fertilization strategies during 2012 to 2014 . Treatments were allocated in a split-plot design with $\mathrm{N}$ (90 or $180 \mathrm{~kg} \mathrm{~N} \mathrm{ha}^{-1}$, bermudagrass study) or harvest frequency ( 6 vs. $12 \mathrm{wk}$, limpograss study) as the main factors and $P\left(0,8.7\right.$, and $\left.17.4 \mathrm{~kg} \mathrm{P} \mathrm{ha}^{-1}\right)$ and $\mathrm{K}\left(0,33\right.$, and $\left.66 \mathrm{~kg} \mathrm{~K} \mathrm{ha}^{-1}\right)$ levels as subplots. Bermudagrass HA increased linearly (up to $377 \%$ in Year 3) as $\mathrm{K}$ level increased. Similarly, $\mathrm{K}$ fertilization increased limpograss HA from 8.4 to $11.6 \mathrm{Mg} \mathrm{ha}^{-1}$ in 2013 and from 5.8 to $15.7 \mathrm{Mg} \mathrm{ha}^{-1}$ in 2014 as $\mathrm{K}$ levels increased from 0 to $66 \mathrm{~kg} \mathrm{~K} \mathrm{ha}^{-1}$; however, no effect was observed in 2012. Bermudagrass HA and ground cover decreased from 2012 to 2014 in all K treatments. Conversely, decreases in limpograss HA and ground cover over time were observed only in the control (no K) treatments. Bermudagrass and limpograss crude protein concentrations generally decreased with increased $\mathrm{K}$ level. No effects of $\mathrm{N}$ or $\mathrm{P}$ were observed. Continuous aboveground removal without proper $\mathrm{K}$ fertilization is detrimental to bermudagrass and limpograss production and persistence.
\end{abstract}

M.L. Silveira, J.M.B. Vendramini, and H.M.S. da Silva, Univ. of Florida, Range Cattle Research and Education Center, Ona, FL 33865; B.M.M.N. Borges, Faculdade de Ciências Agrárias e Veterinárias, UNESP-Univ. Estadual Paulista, Campus Jaboticabal, Brazil; V.S. Ribeirinho, Instituto Agronômico, Campinas, Brazil; J.J.J. Lacerda, Univ. Federal do Piauí, Bom Jesus, Brazil; M.V. Azenha, EMBRAPA, Southeast Livestock, Sao Carlos, Brazil; P.R.A. Viegas, Univ. Federal de Sergipe, Aracaju, Brazil; A.D. Aguiar, DeLaval, South Bannockburn, IL 60015. Received 3 Mar 2017. Accepted 28 Apr. 2017. ^Corresponding author(mlas@ufl.edu).

Abbreviations: $\mathrm{CP}$, crude protein; HA, herbage accumulation; IVDOM, in vitro digestible organic matter.

T $\mathrm{N}$ the southeastern United States, most forage-based livestock systems rely on warm-season perennial grasses such as bermudagrass [Cynondon dactylon (L.) Pers.] and bahiagrass (Paspalum notatum Flugge) as the main source of nutrients for animals. In Florida, bahiagrass is the predominant cultivated grass, occupying $\sim 1$ million ha in the state (Newman et al., 2011), and is mainly used in low-input systems with low (or no) fertilizer inputs. More productive grasses such as bermudagrass and limpograss (Hemarthria altissima Stapf. and Hubbard) are also important forage crops for livestock producers in Florida because of greater herbage accumulation and nutritive value (Vendramini et al., 2010). However, these grass species require relatively greater fertilization levels than less productive grasses such as bahiagrass (Burton and Hanna, 1995).

While 'Jiggs' bermudagrass and 'Floralta' limpograss respond favorably to $\mathrm{N}$ fertilization, these grasses also require large amounts of $\mathrm{K}$ and $\mathrm{P}$ to sustain desirable forage production and long-term sward persistence (Snyder and Cisar, 2000; Adjei et al., 2001; Sartain, 2002). Reduction in herbage accumulation (HA) due to low $\mathrm{K}$ and $\mathrm{P}$ supply has been documented in several previous studies. For instance, Snyder and Kretschmer (1986) demonstrated that limpograss and bermudagrass HA decreased

Published in Crop Sci. 57:2881-2890 (2017).

doi: 10.2135/cropsci2017.03.0147

(C) Crop Science Society of America 5585 Guilford Rd., Madison, WI 53711 USA All rights reserved. 
linearly as K fertilization level decreased. Similarly, Adjei et al. (2001) also reported a linear decrease in limpograss $\mathrm{HA}$ as $\mathrm{P}$ fertilization levels decreased. In addition to increasing HA, research has also demonstrated that adequate $\mathrm{K}$ and $\mathrm{P}$ supply is often associated with long-term persistence and disease and insect resistance of warm-season grass pastures (Adams and Twersky, 1960; Keisling et al., 1979; Turner and Hummel, 1992; Robinson, 1985; Burton et al., 1997). However, the extent of warm-season grass responses to $\mathrm{K}$ or $\mathrm{P}$ fertilization varies considerably depending on the forage species, soil type, and management history (Adjei et al., 2001). Because N fertilization has the greatest potential to increase HA and nutritive value, greater levels of $\mathrm{N}$ fertilization can also increase $\mathrm{K}$ and $\mathrm{P}$ requirements of forage crops (Anderson et al., 2016)

According to the University of Florida fertilizer recommendations for bermudagrass and limpograss hayfields and pastures, $\mathrm{K}$ and $\mathrm{P}$ fertilization is required when soil tests are low $\left(\leq 25 \mathrm{mg} \mathrm{kg}^{-1}\right.$ of Mehlich-3 extractable $\left.\mathrm{P}\right)$ in $\mathrm{P}$ or are medium or low $\left(\leq 26 \mathrm{mg} \mathrm{kg}^{-1}\right.$ of Mehlich-3 extractable K) in K (Mylavarapu et al., 2013). Recommended P and $\mathrm{K}$ fertilization levels for established bermudagrass and limpograss pastures range from 8.7 to $17.4 \mathrm{~kg} \mathrm{P} \mathrm{ha}^{-1}$ and from 16 to $66 \mathrm{~kg} \mathrm{~K} \mathrm{ha}^{-1}$, respectively. However, numerous field observations in Florida suggested that most forage producers in the state do not supply adequate $\mathrm{K}$ and $\mathrm{P}$ fertilizer to replace the amounts of these nutrients that are exported with harvested forage. Because limpograss and bermudagrass can export near equal amounts of $\mathrm{N}$ and K (Adjei et al., 2001; Anderson et al., 2016), soil K deficiency can have major negative impacts on forage production and stand persistence. There have been a number of recent cases of bermudagrass stand decline reported in Florida, mainly in mechanically harvested forage production systems due to lack (or inadequate) K fertilization (Silveira et al., 2013). These failures were typically observed in hayfields receiving $\mathrm{N}$ fertilization only and harvested multiple times per year. In addition, most soils in Florida exhibit low cation exchange capacity and do not retain large amounts of $\mathrm{K}$ and $\mathrm{P}$, even after receiving fertilizer (Erickson et al., 2005); therefore, these nutrients can be lost through leaching and often must be applied to maintain adequate levels to sustain limpograss and bermudagrass growth and stand integrity.

Another important aspect that supports a more comprehensive soil fertility approach is the fact that low $\mathrm{K}$ and $\mathrm{P}$ supply may also limit the ability of the plants to utilize the applied N, which, in turn, can also have detrimental economic and environmental impacts. While addition of $\mathrm{N}$ is expected to increase forage HA, it also stimulates additional uptake of other nutrients (Robinson, 1996). However, when soil $\mathrm{K}$ and $\mathrm{P}$ availability is limiting, forage response to $\mathrm{N}$ fertilization can also be reduced (Robinson, 1985). Although $\mathrm{K}$ and $\mathrm{P}$ fertilization is not expected to have direct impacts on forage nutritive value, reduced $\mathrm{N}$ use efficiency due to $\mathrm{K}$ and $\mathrm{P}$ deficiency may, in turn, decrease forage nutritive value. Although the effects of $\mathrm{K}$ and $\mathrm{P}$ on bermudagrass have been extensively examined, there is limited information regarding minimum $\mathrm{P}$ and $\mathrm{K}$ fertilization strategies that can sustain adequate limpograss and bermudagrass production when these grasses are grown in sandy soils (980 $\mathrm{g} \mathrm{kg}^{-1}$ sand) with limited nutrient-holding capacity (cation exchange capacity of $5.5 \mathrm{cmol} \mathrm{kg}^{-1}$ soil). The objective of this study was to evaluate bermudagrass and limpograss HA, nutritive value, and persistence to $\mathrm{K}$ and $\mathrm{P}$ fertilization. Emphasis was placed on minimum fertilization regimens that could maintain optimum HA, nutritive value, and stand persistence.

\section{MATERIAL AND METHODS}

A 3-yr study was conducted on established Jiggs bermudagrass and Floralta limpograss fields at the University of Florida, Range Cattle Research and Education Center, Ona, FL $\left(27^{\circ} 23^{\prime} \mathrm{N}\right.$, $81^{\circ} 56^{\prime} \mathrm{W}, 24 \mathrm{~m}$ asl) on an Ona fine sand (sandy, siliceous, hyperthermic Typic Alaquods). Before initiation of the study, the experimental area was subjected to occasional mechanical harvest for hay. The sites had no previous history of $\mathrm{P}$ or $\mathrm{K}$ fertilization during the past $5 \mathrm{yr}$. Two experiments, herein referred to as bermudagrass and limpograss studies, were established in 2012 to evaluate forage responses to different $\mathrm{P}$ and $\mathrm{K}$ fertilization strategies. Plot size was $6 \times 3 \mathrm{~m}$ for the bermudagrass study and $4 \times 3 \mathrm{~m}$ for limpograss, with a $3-\mathrm{m}$ alley between plots. Treatments were allocated in a split-plot arrangement of a randomized complete block design with four replicates.

\section{Bermudagrass Study}

Treatments were arranged in a split-plot design with $\mathrm{N}$ as the main plot (90 or $180 \mathrm{~kg} \mathrm{~N} \mathrm{ha}{ }^{-1}$ ) and $\mathrm{P}(0,8.7$, and $17.4 \mathrm{~kg}$ $\left.\mathrm{P} \mathrm{ha}^{-1}\right)$ and $\mathrm{K}\left(0,33\right.$, and $\left.66 \mathrm{~kg} \mathrm{~K} \mathrm{ha}{ }^{-1}\right)$ as the subplots. The fertilization levels of $180 \mathrm{~kg} \mathrm{~N} \mathrm{ha}^{-1}, 17.4 \mathrm{~kg} \mathrm{P} \mathrm{ha}^{-1}$, and $66 \mathrm{~kg}$ $\mathrm{K} \mathrm{ha}^{-1}$ corresponded to the University of Florida recommendations for established bermudagrass pastures (Mylavarapu et al., 2013). In this study, we also investigated the effects of reduced $\mathrm{P}$ and $\mathrm{K}$ levels (corresponding to 0 or 0.5 times the recommended levels) on Jiggs bermudagrass responses. Since $\mathrm{N}$ fertilization is expected to influence bermudagrass $\mathrm{K}$ and $\mathrm{P}$ requirements (Anderson et al., 2016), two levels of $\mathrm{N}$ fertilization (90 or $180 \mathrm{~kg} \mathrm{~N} \mathrm{ha}^{-1}$ ) were evaluated. Nitrogen was applied as ammonium nitrate and $\mathrm{P}$ and $\mathrm{K}$ as super triple phosphate and potassium chloride, respectively. Fertilizer was applied on 1 May 2012, 30 Apr. 2013, and 29 Apr. 2014.

Forage was harvested at 6-wk regrowth intervals for a total of four harvests per year. During each harvest, two $1-\mathrm{m} \times 3-\mathrm{m}$ forage strips were harvested from each plot to $7.5-\mathrm{cm}$ stubble height using a customized John Deer F935 forage harvester. The remaining herbage was harvested to the same stubble height using a flail harvester and removed from the experimental area. Forage samples were dried at $60^{\circ} \mathrm{C}$ for $48 \mathrm{~h}$ for HA and tissue N, P, and $\mathrm{K}$ determinations. Samples were ground to pass through a $1-\mathrm{mm}$ mesh screen in a Wiley mill (Model 4, Thomas Wiley, Laboratory Mill, Thomas Scientific) and 
analyzed for total $\mathrm{N}$ by dry combustion using a Flash EA 1112NC elemental analyzer (CE Elantech). Crude protein (CP) was calculated by multiplying $\mathrm{N}$ concentration by 6.25 . Tissue $\mathrm{P}$ and $\mathrm{K}$ concentrations were determined using the Kjeldahl digestion procedure (McKenzie and Wallace, 1954). Phosphorus and $\mathrm{K}$ contents were calculated as the product of tissue $\mathrm{P}$ and $\mathrm{K}$ concentrations and HA for each plot and harvest. Forage samples were also analyzed for in vitro digestible organic matter (IVDOM) using the two-stage technique described by Tilley and Terry (1963), modified by Moore and Mott (1974). Crude protein and IVDOM were measured to describe nutritive value.

Mean undisturbed canopy height was estimated from five measurements per plot before each harvest. Light interception was measured (three random locations per plot) before each harvest using a SunScan (Delta-T Devices). Canopy height and light interception were used as indicators of sward conditions in response to the various fertilization regimens.

Bermudagrass ground cover and plant density (here defined as the number of bermudagrass crowns per unit of area) were estimated visually in the last harvest of 2013 and 2014. A 1- $\mathrm{m}^{2}(1 \times$ $1 \mathrm{~m})$ quadrat was placed in the center of each plot. The quadrat was divided into $10010-\mathrm{cm} \times 10-\mathrm{cm}$ squares, and the proportion of area covered by bermudagrass and the number of bermudagrass crowns were recorded by two observers. The average of two observers and two locations per evaluation event was reported.

\section{Limpograss Study}

Treatments consisted of a factorial arrangement of two harvest frequencies (6- and 12-wk intervals), three $\mathrm{P}(0,8.7$, and $17.4 \mathrm{~kg}$ $\left.\mathrm{P} \mathrm{ha}^{-1}\right)$, and three $\mathrm{K}$ fertilization levels $\left(0,33\right.$, and $\left.66 \mathrm{~kg} \mathrm{~K} \mathrm{ha}^{-1}\right)$ allocated in a split-plot arrangement of a randomized complete block design with four replicates. Because limpograss is often conserved as a stockpiled grass, harvest frequency (four vs. two times per year) was intended to mimic typical limpograss harvest management in Florida. Harvest frequency was considered the main plot, whereas $\mathrm{P}$ and $\mathrm{K}$ were subplots. All plots received $180 \mathrm{~kg} \mathrm{~N} \mathrm{ha}{ }^{-1}$ split into two applications of $90 \mathrm{~kg} \mathrm{~N} \mathrm{ha}^{-1}$ each (May and August of each year). Phosphorus and $\mathrm{K}$ application levels evaluated in this study corresponded to $0,0.5$, or 1 times the recommended levels for limpograss. Nitrogen was applied as ammonium nitrate and $\mathrm{P}$ and $\mathrm{K}$ as super triple phosphate and potassium chloride, respectively. Phosphorus and $\mathrm{K}$ fertilizers were applied on 8 May 2012, 7 May 2013, and 6 May 2014.

Forage was harvested at $6-$ or $12-w k$ intervals to a $20-\mathrm{cm}$ stubble height following the same procedure described in the bermudagrass study. Limpograss $\mathrm{CP}$, tissue $\mathrm{K}$ and $\mathrm{P}$, and IVDOM concentrations, canopy height and light interception, and ground cover were determined following the same procedures described for the bermudagrass study. Herbage accumulation is presented by 12 -wk regrowth intervals and includes one 12 -wk or two 6-wk harvests.

\section{Soil Sampling and Analysis}

Initial soil samples were collected from the $0-$ to $15-\mathrm{cm}$ depth in February 2012 and analyzed for pH and Mehlich-1 P and K extractable concentrations (Mehlich, 1953). At the end of each growing season (November 2012, 2013, and 2014), soil samples were collected and analyzed for the same selected chemical properties. Because initial soil $\mathrm{pH}$ was 5 (Table 1), $1 \mathrm{Mg} \mathrm{ha}^{-1}$ of
Table 1. Selected soil chemical properties $(0-$ to $15-\mathrm{cm}$ depth) for bermudagrass and limpograss fertilization trials conducted on an Ona fine sand in Ona, FL, during 2012, 2013, and 2014.

\begin{tabular}{llcl}
\hline & & \multicolumn{2}{c}{ Mehlich-1 } \\
\cline { 3 - 4 } Sampling date & $\mathrm{pH}$ & $\mathrm{P}$ & $\mathrm{K}$ \\
\cline { 3 - 4 } March 2012 (initial) & $5.3 \mathrm{~b} \dagger$ & $11 \mathrm{a}$ & $6 \mathrm{a}$ \\
November 2012 & & $7 \mathrm{a}$ & $7 \mathrm{a}$ \\
November 2013 & $6.0 \mathrm{a}$ & $5 \mathrm{a}$ & $8 \mathrm{a}$ \\
November 2014 & $5.9 \mathrm{a}$ & $8 \mathrm{a}$ & $7 \mathrm{a}$ \\
SE & $5.8 \mathrm{a}$ & 3 & 1 \\
\hline
\end{tabular}

† Means within a column followed by the same letter are not different using the LSMEANS/PDIFF procedure $(P>0.05)$. Lime was applied at a level of $1 \mathrm{Mg} \mathrm{ha}^{-1}$ after initial soil sampling event in 2012.

$\ddagger$ Values represent the average across all treatments.

lime was applied in March 2012 to increase the $\mathrm{pH}$ to the desirable level of 5.5 (Mylavarapu et al., 2013).

\section{Statistical Analyses}

Response variables for the bermudagrass and limpograss studies (HA, CP, tissue P and K, IVDOM, canopy height, light interception, and ground cover) were analyzed by fitting mixed-effects models using the PROC MIXED procedure of SAS (SAS Institute, 1996). Replicates were considered random effects. In the bermudagrass study, N, P, and $\mathrm{K}$ fertilization, harvest, and year were considered fixed effects, whereas regrowth interval, $\mathrm{P}$ and $\mathrm{K}$ fertilization, harvest, and year were considered fixed effects in the limpograss study. Harvest was analyzed as a repeated measurement using the covariant structure that resulted in the lowest Akaike value. Treatments were considered different when $P \leq 0.05$. Interactions not discussed were not significant $(P>0.05)$. The means reported were least squares means and were compared using PDIFF (SAS Institute, 1996). Single degree of freedom polynomial contrasts were used to test the $\mathrm{P}$ and $\mathrm{K}$ fertilization effects and were considered significant at $P \leq 0.05$.

\section{RESULTS AND DISCUSSION Weather Data}

Temperature patterns observed during the 3 yr study were typical for the region, with exception of below-freezing temperatures that occurred in spring (March) 2013 (Fig. 1). Freezing events in this region typically occur during the months of December to February; thus, the low temperatures experienced in during the spring of 2013 were atypical and resulted in negative impacts on forage production during the 2013 growing season. Annual rainfall observed during the study period was $\sim 20 \%$ below the average in 2012 and 2013 ( 1080 and $1100 \mathrm{~mm}$ in 2012 and 2013, respectively, compared with the 71-yr average of $1356 \mathrm{~mm}$ ) but approached the long-term average in $2014(1288 \mathrm{~mm})$. The drought conditions experienced in the beginning of the 2013 growing season also contributed to decreased forage production during that year. 


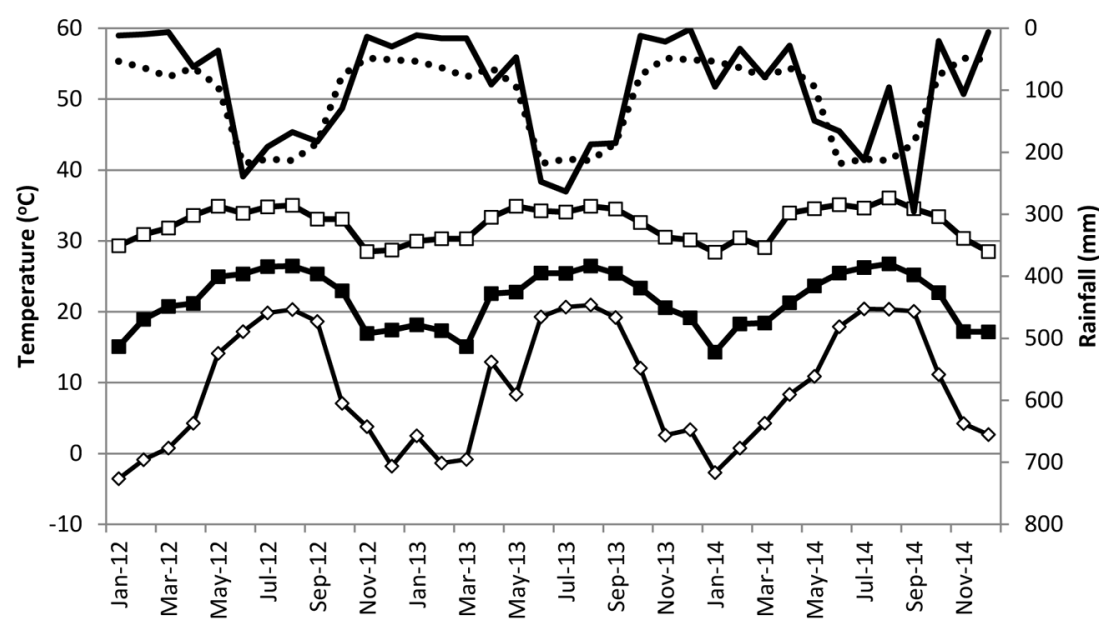

\begin{tabular}{ll|}
$\longrightarrow$ Mean Temperature & $\sim$ Minimum Temperature \\
$-\square-$ Maximum Temperature & Rainfall $(\mathrm{mm})$ \\
-... 71-yr Mean Rainfall $(\mathrm{mm})$ & \\
\hline
\end{tabular}
Fig. 1. Observed and 71-yr average monthly rainfall and temperature during 2012, 2013, and 2014.

\section{Bermudagrass Herbage Accumulation}

There was a linear increase in bermudagrass $\mathrm{HA}$ as $\mathrm{K}$ levels increased from 0 to $66 \mathrm{~kg} \mathrm{~K} \mathrm{ha}^{-1}(P<0.0001)$ (Table 2). Averaged across the $3 \mathrm{yr}$ of study, annual bermudagrass HA increased by 160 to $242 \%$ relative to the control treatments when $\mathrm{K}$ was applied at 33 and $66 \mathrm{~kg}$ $\mathrm{K} \mathrm{ha}{ }^{-1}$, respectively. However, the magnitude of differences between treatments receiving $\mathrm{K}$ and no $\mathrm{K}$ increased from 2012 to 2014. Application of $66 \mathrm{~kg} \mathrm{~K} \mathrm{ha}^{-1}$ increased bermudagrass HA by $\sim 44,307$, and $376 \%$ in 2012, 2013, and 2014, respectively, compared with the control treatment. Similarly, at the $\mathrm{K}$ level of $33 \mathrm{~kg} \mathrm{~K} \mathrm{ha}^{-1}$, bermudagrass HA increased $26 \%$ in 2012 compared with $252 \%$ in 2014 . These results are consistent with previous studies that documented bermudagrass HA increases in response to $\mathrm{K}$ fertilization (Robinson, 1985; Snyder and Kretschmer, 1986; Jones and Watson, 1991; Burton et al., 1997). However, the magnitude of bermudagrass $\mathrm{HA}$ increases, attributed to $\mathrm{K}$ fertilization observed in the current study, was greater than that reported in previous reports. Studying common bermudagrass responses to $\mathrm{K}$ fertilization in two silt loam soils from Arkansas, Slaton et al. (2007) observed a $36 \%$ increase in bermudagrass $\mathrm{HA}$ when $\mathrm{K}$ was annually applied at $93 \mathrm{~kg} \mathrm{~K} \mathrm{ha}^{-1}$ (mean HA of $14.6 \mathrm{Mg} \mathrm{ha}^{-1}$ ) compared with the no $\mathrm{K}$ treatment (mean HA of $10.8 \mathrm{Mg} \mathrm{ha}^{-1}$ ). In a 4-yr study in Texas, Haby et al. (2007) reported a $22 \%$ increase in 'Tifton 85 ' bermudagrass HA when $\mathrm{K}$ was applied at $125 \mathrm{~kg} \mathrm{~K} \mathrm{ha}^{-1}$ compared with no K application. Similarly, Nelson et al. (1983) observed a 50\% increase in bermudagrass HA when $\mathrm{K}$ was applied at an annual level of $156 \mathrm{~kg} \mathrm{~K} \mathrm{ha}^{-1}$ on a fine sandy loam soil in east Texas.

Despite the vast literature indicating that warmseason grasses respond favorably to $\mathrm{N}$ (Wilkinson and Langdale, 1974; Silveira et al., 2007), no effect $(P=0.17)$ of $\mathrm{N}$ application level was observed on bermudagrass HA (mean HA of $3.7 \mathrm{Mg} \mathrm{ha}^{-1}$ for treatments receiving $90 \mathrm{~kg}$ $\mathrm{N} \mathrm{ha}^{-1}$ vs. $4.2 \mathrm{Mg} \mathrm{ha}^{-1}$ for the treatments receiving $180 \mathrm{~kg}$ $\mathrm{N} \mathrm{ha}^{-1}$ ). Lack of bermudagrass response to $\mathrm{N}$ occurred because $\mathrm{K}$ deficiency was likely the main factor limiting forage production. Although addition of $\mathrm{N}$ increases HA, it also stimulates additional uptake of K (Haby et al., 2007; Kering et al., 2011); thus, if soil $\mathrm{K}$ concentration is low, forage response to $\mathrm{N}$ fertilization can be also reduced.

Table 2. Bermudagrass herbage accumulation (HA), density, and ground cover as affected by year $x$ K fertilization level interaction.

\begin{tabular}{|c|c|c|c|c|c|c|c|}
\hline \multirow[b]{2}{*}{ K level } & \multicolumn{3}{|c|}{ HA } & \multicolumn{2}{|c|}{ Density } & \multicolumn{2}{|c|}{ Ground cover } \\
\hline & 2012 & 2013 & 2014 & 2013 & 2014 & 2013 & 2014 \\
\hline & $-N$ & - & 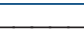 & - & 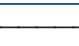 & - & - \\
\hline 0 & 4.5†ał & $1.1 \mathrm{~b}$ & $1.1 \mathrm{~b}$ & $37 a$ & $33 a$ & $31 a$ & $34 a$ \\
\hline 33 & $5.7 a$ & $3.2 \mathrm{c}$ & $4.0 \mathrm{~b}$ & $76 a$ & $64 b$ & $73 a$ & $58 b$ \\
\hline 66 & $6.5 a$ & $4.3 c$ & $5.4 b$ & $86 a$ & $76 b$ & $86 a$ & $62 \mathrm{~b}$ \\
\hline SE & 0.3 & 0.1 & 202 & \multicolumn{2}{|c|}{2.7} & \multicolumn{2}{|c|}{2.7} \\
\hline Polynomial contrast§ & $L^{\star \star \star}$ & $L^{\star \star \star}$ & $L^{\star \star \star}$ & \multicolumn{2}{|c|}{$L^{\star \star \star}, Q^{\star \star \star}$} & \multicolumn{2}{|c|}{$L^{\star \star \star}, Q^{\star \star \star}$} \\
\hline
\end{tabular}

*** Significant at the 0.001 probability level.

† Data are means across two $\mathrm{N}$ levels, three P levels, and four replicates $(n=24)$.

$\ddagger$ Means within a row followed by the same letter are not different using the LSMEANS/PDIFF procedure $(P>0.05)$.

$\S$ L, linear; Q, quadratic. 
Similarly, P fertilization showed no effect on bermudagrass HA $(P=0.53)$. A number of previous studies in Florida have demonstrated that adequate forage production can be obtained using little or no P fertilizer input (Rechcigl et al., 1992, 1995; Adjei et al., 1998, 2000). Lack of forage response to $\mathrm{P}$ fertilization is mainly due to $\mathrm{P}$ accumulation in the subsurface Bh horizon, which represents an important supply of $\mathrm{P}$ to pastures growing on Spodosols in Florida (Obour et al., 2011a, 2011b).

Despite the positive effect of $\mathrm{K}$ fertilization on bermudagrass HA, there was a decrease in annual HA from 2012 to 2014 (Table 2). The largest decreases in HA were observed for the treatments receiving no K (75 to 77\% HA reduction in 2013 and 2014 compared with 2012). As K levels increased from 0 to $66 \mathrm{~kg} \mathrm{ha}^{-1}$, the decrease in annual $\mathrm{HA}$ over time was less pronounced. At the highest $\mathrm{K}$ fertilization level, annual bermudagrass HA decreased by $34 \%$ in 2013 and 18\% in 2014 compared with the 2012 growing season. These data indicated that $\mathrm{K}$ levels being applied during the course of this study were not sufficient to sustain the same level of production. In addition, lack of rainfall and low temperatures experienced in the beginning of 2013 growing season (Fig. 1) contributed to relatively lesser HA during this year. Severe infestation of spittlebug [Prosapia bicincta (Say)] experienced in October 2014 across the entire experimental area prevented the last harvest from occurring and reduced annual HA in 2014. Although monthly average temperature recorded in 2014 was typical for the region, seven consecutive days with temperatures $<0^{\circ} \mathrm{C}$ that occurred between 16 and 22 Jan. 2014 also decreased $\mathrm{HA}$, particularly for the control treatments.

There was an effect of harvest $\times \mathrm{K}$ level interaction on bermudagrass herbage mass (Table 3 ). Herbage mass generally increased as $\mathrm{K}$ fertilization levels increased, with the exception of the last harvest of each year. The greatest herbage mass was generally in the first harvest of the season and decreased as the growing season progressed. This response is consistent with other studies that also reported temporal variability and relatively slow rate of bermudagrass growth late in the growing season (Adjei et al., 2001; Slaton et al., 2007).

Corroborating the temporal changes in HA throughout the experimental period, there was a year $\times \mathrm{K}$ fertilization interaction for ground cover and plant density. Ground cover and density decreased for all $\mathrm{K}$ fertilization levels from 2012 to 2014, particularly for the treatments receiving no $\mathrm{K}$ (Table 2 ). Bermudagrass density and ground cover were 76 and $62 \%$, respectively, in the treatments receiving $66 \mathrm{~kg} \mathrm{~K} \mathrm{ha}{ }^{-1}$ compared with $33 \%$ in the control treatment after $3 \mathrm{yr}$ of defoliation. Similar results were also reported by Keisling et al. (1979) studying 'Coastal' bermudagrass responses to $\mathrm{K}$ fertilization (at levels ranging from 0 to $224 \mathrm{~kg} \mathrm{~K} \mathrm{ha}^{-1}$ ) on a loamy soil in Texas. These authors concluded that inadequate $\mathrm{K}$
Table 3. Bermudagrass herbage mass as affected by $\mathrm{K}$ fertilization level and harvest.

\begin{tabular}{|c|c|c|c|c|}
\hline \multirow{3}{*}{$\begin{array}{l}\text { Harvest } \\
\text { event }\end{array}$} & \multicolumn{3}{|c|}{ Herbage mass $†$} & \multirow{3}{*}{$\begin{array}{c}\text { Polynomia } \\
\text { contrast }\end{array}$} \\
\hline & \multicolumn{3}{|c|}{ K level } & \\
\hline & $0 \mathrm{~kg} \mathrm{ha}^{-1}$ & $33 \mathrm{~kg} \mathrm{ha}^{-1}$ & $66 \mathrm{~kg} \mathrm{ha}^{-1}$ & \\
\hline & $\longrightarrow$ & $-\mathrm{Mg} \mathrm{ha}^{-1}$ & 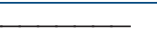 & \\
\hline \multicolumn{5}{|l|}{2012} \\
\hline 1 & $1.8 \mathrm{a} \S$ & $2.3 a$ & $2.4 a$ & $L^{* \star \star}$ \\
\hline 2 & $1.1 \mathrm{c}$ & $1.5 c$ & $1.8 b$ & $L^{\star \star \star *}$ \\
\hline 3 & $1.4 \mathrm{ba}$ & $1.7 \mathrm{~b}$ & $2.0 b$ & $L^{\star \star \star}$ \\
\hline 4 & $0.2 \mathrm{dA}$ & $0.2 d$ & $0.3 \mathrm{c}$ & NS \\
\hline SE & & 0.09 & & \\
\hline \multicolumn{5}{|l|}{2013} \\
\hline 1 & $0.7 a$ & $1.6 a$ & 2.0a & $L^{\star \star \star}$ \\
\hline 2 & $0.2 b$ & $0.8 b$ & $1.1 \mathrm{~b}$ & $L^{\star \star *}$ \\
\hline 3 & $0.2 b$ & $0.8 b$ & $1.2 \mathrm{~b}$ & $L^{\star \star \star}$ \\
\hline 4 & $0.07 b$ & $0.2 \mathrm{c}$ & $0.3 c$ & NS \\
\hline SE & & 62 & & \\
\hline \multicolumn{5}{|l|}{2014} \\
\hline 1 & $0.2 b$ & $1.2 \mathrm{~b}$ & $2.1 \mathrm{a}$ & $L^{\star \star *}$ \\
\hline 2 & $0.7 a$ & $1.8 \mathrm{a}$ & $1.9 a$ & $L^{\star \star \star}$ \\
\hline 3 & $0.2 b$ & $1.0 b$ & $1.3 b$ & $L^{* \star *}$ \\
\hline SE & & 0.1 & & \\
\hline
\end{tabular}

${ }^{\star * \star}$ Significant at the 0.001 probability level.

† Data are means across two $\mathrm{N}$ levels, three $\mathrm{P}$ levels, and four replicates $(n=24)$. ‡ L, linear; NS, not significant.

$\S$ Means within column followed by the same lowercase letter are not different using the LSMEANS/PDIFF procedure $(P>0.05)$

availability reduced tissue $\mathrm{K}$ concentration, rhizome production, and overall root vigor with concomitant negative impacts on stand integrity.

\section{Bermudagrass Nutritive Value}

There was a year $\times \mathrm{K}$ fertilization $\times$ harvest effect on CP concentration (Table 4). Crude protein generally decreased linearly as $\mathrm{K}$ levels increased from 0 to $66 \mathrm{~kg} \mathrm{~K}$ $\mathrm{ha}^{-1}$, with the exception of the first harvest events in 2012 and 2013 The decreases in CP concentrations in response to $\mathrm{K}$ fertilization occurred because of a dilution effect as a result of greater HA observed in the treatments receiving greater levels of K. Regardless of K level, the largest CP concentrations were observed in the first harvest event, generally decreased as the growing season progressed.

Bermudagrass CP concentrations were affected by $\mathrm{N}$ fertilization level $(P=0.04)$, but the $\mathrm{N} \times \mathrm{K}$ interaction was not significant $(P=0.7)$. Mean $\mathrm{CP}$ concentration increased from 132 to $144 \mathrm{~g} \mathrm{~kg}^{-1}$ as $\mathrm{N}$ level increased from 80 to $160 \mathrm{~kg} \mathrm{~N} \mathrm{ha}^{-1}$. No treatment effect was observed on bermudagrass IVDOM. On average, IVDOM concentrations observed in the current study ranged from 362 to $435 \mathrm{~g} \mathrm{~kg}^{-1}$.

Tissue $\mathrm{K}$ concentration was affected by the year $\times \mathrm{K}$ level interaction $(P=0.0012)$ (Table 5$)$. Although tissue $\mathrm{K}$ concentrations decreased over time for the treatments receiving 0 or $33 \mathrm{~kg} \mathrm{~K} \mathrm{ha}^{-1}$, no year effect was observed in 
Table 4. Bermudagrass crude protein concentration as affected by $\mathrm{K}$ fertilization level and harvest.

\begin{tabular}{|c|c|c|c|c|}
\hline \multirow{3}{*}{$\begin{array}{l}\text { Harvest } \\
\text { event }\end{array}$} & \multicolumn{3}{|c|}{ Crude protein } & \multirow{3}{*}{$\begin{array}{c}\text { Polynomial } \\
\text { contrast }\end{array}$} \\
\hline & \multicolumn{3}{|c|}{ K level } & \\
\hline & $0 \mathrm{~kg} \mathrm{ha}^{-1}$ & $33 \mathrm{~kg} \mathrm{ha}^{-1}$ & $66 \mathrm{~kg} \mathrm{ha}^{-1}$ & \\
\hline & $\longrightarrow$ & $-\mathrm{g} \mathrm{kg}^{-1}$ & 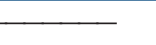 & \\
\hline \multicolumn{5}{|l|}{2012} \\
\hline 1 & $174 a \S$ & $172 a$ & $169 a$ & NS \\
\hline 2 & $157 b$ & $126 b$ & $150 b$ & $Q^{\star \star}$ \\
\hline 3 & $139 c$ & $127 b$ & $122 \mathrm{C}$ & $L^{\star \star \star}$ \\
\hline 4 & $149 c$ & $141 b$ & $134 \mathrm{bc}$ & $L^{\star \star \star}$ \\
\hline SE & & 7 & & \\
\hline \multicolumn{5}{|l|}{2013} \\
\hline 1 & $165 a$ & $164 a$ & $154 a$ & NS \\
\hline 2 & $151 b$ & $134 b$ & $124 \mathrm{bc}$ & $L^{\star \star \star}$ \\
\hline 3 & $146 b$ & $127 b$ & $116 c$ & $L^{\star \star \star}$ \\
\hline 4 & $136 \mathrm{c}$ & $132 b$ & $127 b$ & $L^{*}$ \\
\hline SE & & 3 & & \\
\hline \multicolumn{5}{|l|}{2014} \\
\hline 1 & $163 a$ & $142 a$ & $126 a$ & $L^{\star \star \star}$ \\
\hline 2 & $130 b$ & $107 \mathrm{c}$ & $96 c$ & $L^{\star \star \star}$ \\
\hline 3 & $140 c$ & $127 b$ & $114 b$ & $L^{\star \star \star}$ \\
\hline SE & & 4 & & \\
\hline
\end{tabular}

* Significant at the 0.05 probability level.

** Significant at the 0.01 probability level.

*** Significant at the 0.001 probability level.

† Data are means across two $\mathrm{N}$ levels, three $\mathrm{P}$ levels, and four replicates $(n=24)$.

‡ NS, not significant; L, linear; Q, quadratic.

$\S$ Means within a column followed by the same lowercase letter are not different using the LSMEANS/PDIFF procedure $(P>0.05)$.

the treatments receiving the greatest $\mathrm{K}$ level $\left(66 \mathrm{~K} \mathrm{ha}^{-1}\right)$. Tissue $\mathrm{K}$ concentrations observed in the current study were smaller than those reported in previous studies with bermudagrass (Sartain, 2002; Haby et al., 2007; Slaton et al., 2007), possibly due to the insufficient $\mathrm{K}$ fertilization levels and low soil $\mathrm{K}$ concentrations. No effect of $\mathrm{K}$ fertilization was observed on tissue $\mathrm{P}$ concentration (average tissue $\mathrm{P}$ concentration of $\left.2.7 \mathrm{~g} \mathrm{~kg}^{-1}\right)$. However, tissue $\mathrm{P}$ concentration increased linearly $(P<0.0001)$ in response to $\mathrm{P}$ application. On average, tissue $\mathrm{P}$ concentrations were $2.3 \mathrm{~g} \mathrm{~kg}^{-1}$ for the control treatment and 2.6 and $2.7 \mathrm{~g}$ $\mathrm{kg}^{-1}$ for the treatments receiving 8.7 and $17.4 \mathrm{~kg} \mathrm{P} \mathrm{ha}^{-1}$, respectively. Silveira et al. (2011) observed that tissue P concentrations $>15 \mathrm{~g} \mathrm{~kg}^{-1}$ showed no effect on bahiagrass HA. In spite of the greater tissue $\mathrm{P}$ concentrations, there was no increase in HA with greater P fertilization levels. This result suggested that soil P levels were likely sufficient to maintain bermudagrass growth.

\section{Jiggs Light Interception, Canopy Height, and $P$ and $K$ Accumulation in the Aboveground Biomass}

Light interception and canopy height were affected by the year $\times \mathrm{K}$ interaction $(P<0.0001)$ (Table 5). Light interception and canopy height increased linearly as $\mathrm{K}$ level increased. Similar to HA, light interception and canopy height decreased with time. The largest reductions in canopy height occurred in the treatments receiving no $\mathrm{K}$ (39 cm in 2012 vs. $6.3 \mathrm{~cm}$ in 2014). Canopy light interception values obtained in the current study were generally below the optimum level of $95 \%$ proposed by da Silva and Nascimento (2007) and da Silva et al. (2015) for warmseason grasses. The only exception was the treatment receiving the greatest $\mathrm{K}$ level, which exhibited 97\% light interception in 2012. The reduction in light interception with time was consistent with the decrease in bermudagrass ground cover.

Year and $\mathrm{K}$ level showed significant $(P<0.0001)$ effects on $\mathrm{P}$ and $\mathrm{K}$ content in the aboveground biomass. Increased level of $\mathrm{K}$ fertilization generally resulted in increases in bermudagrass $\mathrm{K}$ and $\mathrm{P}$ content (Table 6). Average $\mathrm{K}$ content reported in this study (range of 13.7 to $51.2 \mathrm{~kg} \mathrm{~K} \mathrm{ha}{ }^{-1}$ ) was smaller than those reported in previous studies for other bermudagrass cultivars. Haby et al. (2007) and Slaton et al. (2007) reported K uptake ranging from 130 to $257 \mathrm{~kg} \mathrm{~K} \mathrm{ha}^{-1}$ in common and Tifton 85 bermudagrass plots receiving no $\mathrm{K}$ fertilization. Since annual

Table 5. Bermudagrass crude protein, tissue $\mathrm{K}$ concentrations, height, and light interception as affected by year and $\mathrm{K}$ fertilization level.

\begin{tabular}{|c|c|c|c|c|c|c|c|c|c|}
\hline \multirow[b]{2}{*}{ K level } & \multicolumn{3}{|c|}{ Tissue $\mathrm{K}$} & \multicolumn{3}{|c|}{ Height } & \multicolumn{3}{|c|}{ Light interception } \\
\hline & 2012 & 2013 & 2014 & 2012 & 2013 & 2014 & 2012 & 2013 & 2014 \\
\hline $\mathrm{kg} \mathrm{ha}^{-1}$ & 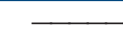 & $\mathrm{g} \mathrm{kg}^{-1}$ & - & $\longrightarrow$ & $-\mathrm{cm}-$ & - & $\longrightarrow$ & $-\%-$ & - \\
\hline 0 & $6.4+a \neq$ & $3.8 \mathrm{~b}$ & $3.7 \mathrm{~b}$ & $39 a$ & $29 b$ & $6 c$ & $71 a$ & $71 a$ & $62 \mathrm{~b}$ \\
\hline 33 & $8.1 \mathrm{a}$ & $6.9 b$ & $6.8 b$ & $43 a$ & $40 b$ & $11 \mathrm{c}$ & $91 \mathrm{a}$ & $85 b$ & $82 \mathrm{~b}$ \\
\hline 66 & $10.4 a$ & $9.9 a$ & $9.8 a$ & $44 a$ & $43 a$ & $13 b$ & $97 a$ & $87 b$ & $85 b$ \\
\hline SE & & 0.3 & & & 1 & & & 1.3 & \\
\hline Polynomial contrast§ & $L^{\star \star \star}$ & $L^{* *}$ & $L^{* \star}$ & $L^{* *}$ & $L^{\star \star \star}$ & $L^{* \star *}$ & $L^{\star \star \star}$ & $L^{* *}$ & $L^{* *}$ \\
\hline
\end{tabular}

** Significant at the 0.01 probability level.

${ }^{* \star \star}$ Significant at the 0.001 probability level.

† Data are means across two $\mathrm{N}$ levels, three $\mathrm{P}$ levels, and four replicates $(n=24)$.

$\ddagger$ Means within row followed by the same letter are not different using the LSMEANS/PDIFF procedure $(P>0.05)$.

$\S \mathrm{L}$, linear. 
Table 6. Bermudagrass $\mathrm{P}$ and $\mathrm{K}$ content in the aboveground biomass as affected by $\mathrm{K}$ fertilization level and year.

\begin{tabular}{lcc}
\hline Effect & P content & K content \\
\cline { 2 - 3 } K level & \multicolumn{2}{c}{$\mathrm{kg} \mathrm{ha}^{-1}$} \\
\cline { 2 - 2 } $\mathrm{kg} \mathrm{ha}^{-1}$ & $6.5 \mathrm{c} \dagger$ & $13.7 \mathrm{c}$ \\
$33 \mathrm{~kg} \mathrm{ha}^{-1}$ & $11.9 \mathrm{~b}$ & $37.1 \mathrm{a}$ \\
$66 \mathrm{~kg} \mathrm{ha}^{-1}$ & $14.7 \mathrm{a}$ & $35.5 \mathrm{~b}$ \\
$\mathrm{SE}$ & 0.7 & 1.7 \\
Year & & \\
2012 & $16.3 \mathrm{a}$ & $51.2 \mathrm{a}$ \\
2013 & $7.3 \mathrm{~b}$ & $29.4 \mathrm{~b}$ \\
2014 & $9.5 \mathrm{c}$ & $28.3 \mathrm{~b}$ \\
$\mathrm{SE}$ & 0.7 & 1.6 \\
\hline
\end{tabular}

† Means within a column followed by the same letter are not different using the LSMEANS/PDIFF procedure $(P>0.05)$.

Jiggs bermudagrass HA was comparable with reports in the literature, differences in $\mathrm{K}$ content are mainly due to small tissue $\mathrm{K}$ and soil $\mathrm{K}$ concentrations observed in the current study. Bermudagrass $\mathrm{P}$ and $\mathrm{K}$ contents also decreased with time. Phosphorus and $\mathrm{K}$ contents observed in 2014 were $\sim 42$ to $45 \%$ smaller than the values reported in 2012. This response suggested that ability of bermudagrass to utilize $\mathrm{K}$ and $\mathrm{P}$ supplied either from fertilizer or soil reserves likely declined over time. No effect of $\mathrm{N}$ fertilization on $\mathrm{P}$ or $\mathrm{K}$ accumulation was observed $(P=$ 0.27 and 0.44 , respectively).

\section{Limpograss HA}

There was a year $\times \mathrm{K}$ fertilization level effect on limpograss HA (Table 7). The interaction occurred because there was no effect of $\mathrm{K}$ fertilization in 2012; however, K fertilization increased HA linearly in 2013 and 2014. Limpograss HA observed in this study is consistent with previous reports (Snyder and Kretschmer, 1986; Adjei et al., 1998, 2001). Compared with the control treatments (no K), $\mathrm{K}$ fertilization at the $66-\mathrm{kg} \mathrm{K} \mathrm{ha}^{-1}$ level increased limpograss HA by $38 \%$ in 2013 and $173 \%$ in 2014. With the exception of the treatments receiving no $\mathrm{K}$, limpograss HA did not decrease over time. Results indicated that, when fertilized with $\mathrm{K}$, limpograss $\mathrm{HA}$ at the end of the 3-yr study either remained the same (treatments receiving $33 \mathrm{~kg} \mathrm{~K} \mathrm{ha}^{-1}$ ) or increased ( $\mathrm{K}$ level of $66 \mathrm{~kg} \mathrm{~K}$ $\mathrm{ha}^{-1}$ ) compared with the first year. Conversely, when no K was applied, limpograss HA decreased $32 \%$ in 2013 and 2014 compared with 2012.

The largest differences between control and treatments receiving $\mathrm{K}$ were observed in 2014 . These results were consistent with Nelson et al. (1983), who also documented negligible effects of $\mathrm{K}$ fertilization on bermudagrass $\mathrm{HA}$ in the first year. These authors reported that, as soil $\mathrm{K}$ became depleted, larger increases in forage yield were observed during the second and third years of the study. Adjei et al. (1998) reported no effect of K on limpograss HA during the first year of study; however, these authors observed a 34\% increase in limpograss HA in Year 2 for treatments fertilized with $\mathrm{K}\left(56 \mathrm{~kg} \mathrm{~K} \mathrm{ha}^{-1}\right)$ and $\mathrm{P}\left(29 \mathrm{~kg} \mathrm{P} \mathrm{ha}{ }^{-1}\right)$. Corroborating our results, Adjei et al. (2001) observed no limpograss response to K fertilization (at levels of 0 to $148 \mathrm{~kg} \mathrm{~K} \mathrm{ha}^{-1}$ ) in Year 1; however, a quadratic response was observed in Year 2, with the greatest HA obtained at $\mathrm{K}$ levels of $74 \mathrm{~kg} \mathrm{~K} \mathrm{ha}^{-1}$.

Limpograss harvested at $12 \mathrm{wk}$ had greater HA than the 6 -wk (12.9 vs. $\left.8.9 \mathrm{Mg} \mathrm{ha}^{-1}, P<0.0001, \mathrm{SE}=327\right)$ frequency. This difference corresponded to $\sim 44 \%$ more biomass by extending the harvest frequency from 6 to 12 wk. No effect of $\mathrm{P}$ fertilization on limpograss HA was observed $\left(P=0.57, \mathrm{SE}=400\right.$, mean $\left.=11.0 \mathrm{Mg} \mathrm{ha}^{-1}\right)$.

There was a linear increase in limpograss density and ground cover as $\mathrm{K}$ levels increased (Table 7). In absence of $\mathrm{K}$ fertilization, limpograss density and ground cover decreased $\sim 22 \%$ in 2014 compared with the previous year.

Table 7. Limpograss herbage accumulation (HA), density, ground cover, crude protein, and $\mathrm{K}$ and $\mathrm{P}$ content in aboveground biomass as affected by year $\times \mathrm{K}$ fertilization level interaction.

\begin{tabular}{|c|c|c|c|c|c|c|c|c|c|c|c|c|c|c|c|c|}
\hline \multirow{2}{*}{$\begin{array}{l}\text { K } \\
\text { fertilization } \\
\text { level }\end{array}$} & \multicolumn{3}{|c|}{$\mathrm{HA}$} & \multicolumn{2}{|c|}{ Density } & \multicolumn{2}{|c|}{ Ground cover } & \multicolumn{3}{|c|}{ Crude protein } & \multicolumn{3}{|c|}{$\mathrm{P}$ content } & \multicolumn{3}{|c|}{ K content } \\
\hline & 2012 & 2013 & 2014 & 2013 & 2014 & 2013 & 2014 & 2012 & 2013 & 2014 & 2012 & 2013 & 2014 & 2012 & 2013 & 2014 \\
\hline- & $-\mathrm{kg} \mathrm{ha}^{-1}$ & & 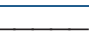 & \multicolumn{4}{|c|}{$\%$} & \multicolumn{3}{|c|}{$\mathrm{g} \mathrm{kg}^{-1}$} & \multicolumn{6}{|c|}{$\longrightarrow \mathrm{kg} \mathrm{ha}^{-1}$} \\
\hline 0 & $12.4 † a \ddagger$ & $8.4 \mathrm{~b}$ & $5.8 \mathrm{c}$ & $91 \mathrm{a}$ & $71 b$ & $87 a$ & $68 b$ & $61.9 b$ & $66.6 a b$ & $70.5 \mathrm{a}$ & $15.9 a$ & $11.2 \mathrm{~b}$ & $9.1 b$ & $66.9 a$ & $26.8 b$ & $18.8 \mathrm{~b}$ \\
\hline 33 & $11.06 \mathrm{ab}$ & $9.8 b$ & $12.0 \mathrm{a}$ & $92 a$ & $88 a$ & $93 a$ & $87 a$ & $62.2 \mathrm{a}$ & $61.8 \mathrm{a}$ & $64.2 \mathrm{a}$ & $14.4 \mathrm{a}$ & $12.3 b$ & $14.8 \mathrm{a}$ & 77.1a & 49.1b & $51.4 b$ \\
\hline 66 & $12.1 \mathrm{~b}$ & $11.6 \mathrm{~b}$ & $15.7 a$ & $94 a$ & $94 a$ & $94 a$ & $92 a$ & $61.8 a$ & $60.1 a$ & $58.0 a$ & 15.1ab & $14.1 \mathrm{~b}$ & $17 a$ & $92.6 a$ & 69.0b & $80.9 a$ \\
\hline SE & & 694 & & \multicolumn{2}{|c|}{1.2} & \multicolumn{2}{|c|}{1.4} & \multicolumn{3}{|c|}{1.0} & & & & \multicolumn{3}{|c|}{6.6} \\
\hline $\begin{array}{l}\text { Polynomial } \\
\text { contrast }\end{array}$ & NS§ & $L^{\star \star \star}$ & $L^{\star \star \star}$ & \multicolumn{2}{|c|}{$L^{* *}$} & \multicolumn{2}{|c|}{$L^{\star \star * \star}$} & NS & $L^{*}$ & $L^{\star *}$ & NS & $L^{*}$ & $L^{* \star \star}$ & & $L^{\star \star \star}$ & \\
\hline
\end{tabular}

* Significant at the 0.05 probability level.

** Significant at the 0.01 probability level.

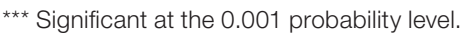

† Data are means across two $\mathrm{N}$ levels, three P levels, and four replicates $(n=24)$.

‡ Means within a row followed by the same letter are not different using the LSMEANS/PDIFF procedure $(P>0.05)$.

$\S$ NS, not significant; L, linear. 
No decline in limpograss ground cover or density over time was observed when K was applied. No effect of limpograss harvest frequency on ground cover or density was observed $(P=0.38)$

\section{Limpograss Nutritive Value}

There was a year $\times \mathrm{K}$ fertilization level interaction effect on CP concentration. The interaction occurred because limpograss CP decreased with increasing K in 2013 and 2014, but there was no difference in 2012. Crude protein concentration decreased 9\% in 2013 and 17\% in 2014 as K levels increased from 0 to $66 \mathrm{~kg} \mathrm{~K} \mathrm{ha}^{-1}$ (Table 6). This response occurred because of greater limpograss $\mathrm{HA}$ in response to $\mathrm{K}$ application, thus resulting in a dilution of $\mathrm{N}$.

Limpograss harvested at 6 wk had greater CP concentrations $\left(79.7 \mathrm{~g} \mathrm{~kg}^{-1}\right)$ than the $12-\mathrm{wk}$ regrowth interval (79.7 vs. $46.3 \mathrm{~g} \mathrm{~kg}^{-1}, P<0.0001, \mathrm{SE}=2$ ). Similarly, IVDOM also decreased from 556 to $522 \mathrm{~g} \mathrm{~kg}^{-1}$ as harvest frequency increased from 6 to $12 \mathrm{wk}$, respectively. Crude protein and IVDOM concentrations observed at the 6-wk harvesting frequency were consistent with the values reported by Adjei et al. (1998; 2001). In general, nutritive value of warm-season grasses decreases with longer regrowth interval due to increase in cell wall and decrease in cell contents (Coleman et al., 2004).

Limpograss tissue $\mathrm{P}$ and $\mathrm{K}$ concentrations were affected by $\mathrm{K}$ fertilization level and regrowth interval (Table 8). Similar to CP concentrations, tissue $\mathrm{P}$ and $\mathrm{K}$ concentrations decreased with increased $\mathrm{K}$ level. Although tissue $\mathrm{P}$ and $\mathrm{K}$ concentrations reported in the current study were consistent with the data published by Adjei et al. (1998) on similar soil and environmental conditions, unlike our results, these authors reported a 55\% increase in limpograss tissue $\mathrm{K}$ concentrations with $\mathrm{K}$ fertilization. Increasing regrowth interval from 6 to $12 \mathrm{wk}$ also resulted in smaller tissue $\mathrm{P}$ and $\mathrm{K}$ concentrations. At the 6-wk harvest frequency, average tissue $\mathrm{P}$ and $\mathrm{K}$ concentrations were 1.8 and $6.4 \mathrm{~g} \mathrm{~kg}^{-1}$, respectively. When limpograss was harvested

Table 8. Limpograss tissue $\mathrm{P}$ and $\mathrm{K}$ concentrations, height, and light interception as affected by $\mathrm{K}$ fertilization level and harvest frequency.

\begin{tabular}{|c|c|c|c|c|}
\hline Effect & Tissue $\mathrm{P}$ & Tissue $\mathrm{K}$ & Height & $\begin{array}{c}\text { Light } \\
\text { interception }\end{array}$ \\
\hline & $\longrightarrow g$ & 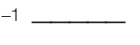 & $\mathrm{cm}$ & $\%$ \\
\hline \multicolumn{5}{|l|}{ K level } \\
\hline $0 \mathrm{~kg} \mathrm{ha}^{-1}$ & $1.5 \mathrm{c} \dagger$ & $3.8 \mathrm{c}$ & $40 b$ & $74 b$ \\
\hline $33 \mathrm{~kg} \mathrm{ha}^{-1}$ & $1.4 b$ & $5.1 b$ & $42 b$ & $80 a$ \\
\hline $66 \mathrm{~kg} \mathrm{ha}^{-1}$ & $1.3 \mathrm{a}$ & $5.9 a$ & $45 a$ & $82 a$ \\
\hline SE & 0.08 & 0.1 & 1 & 2 \\
\hline \multicolumn{5}{|c|}{ Harvest frequency } \\
\hline 6 wk & $1.8 \mathrm{a}$ & $6.4 a$ & $34 b$ & $72 b$ \\
\hline $12 \mathrm{wk}$ & $1.1 \mathrm{~b}$ & $3.6 b$ & $53 a$ & $86 a$ \\
\hline SE & & 0.1 & 1 & 2 \\
\hline
\end{tabular}

† Means within a column followed by the same lowercase letter are not different using the LSMEANS/PDIFF procedure $(P>0.05)$. at 12-wk intervals, average tissue $\mathrm{P}$ and $\mathrm{K}$ concentrations decreased to 1.1 and $3.6 \mathrm{~g} \mathrm{~kg}^{-1}$, respectively. As mentioned above, greater HA at greater regrowth interval resulted in dilution effects of the nutrients in the plant tissue.

\section{Limpograss Light Interception, Canopy Height, and $P$ and $K$ Accumulation in Aboveground Biomass}

Light interception and canopy height were affected by $\mathrm{K}$ levels and harvest frequency $(P<0.0001)$ (Table 8$)$. Light interception and canopy height increased linearly as K level increased. Similar to HA, light interception and canopy height increased $\sim 57$ and $19 \%$, respectively, as interval between harvests increased from 6 to $12 \mathrm{wk}$. Light interception observed in this study ranged from 75 to $82 \%$, which was below the optimum level of $95 \%$ proposed by da Silva and Nascimento (2007). However, because limpograss HA obtained in the current study was similar to previous reports (Snyder and Kretschmer, 1986; Adjei et al., 1998) and treatments receiving the greatest K level exhibited satisfactory stand persistency (as evidenced by 92\% ground cover at the end of the 3-yr study), it is possible that $95 \%$ light interception may not be a reliable indicator of optimum HA or stand integrity for limpograss. Similar results have also been reported by Aguiar et al. (2014), who observed a poor correlation between light interception and Jiggs bermudagrass HA and ground cover.

Limpograss $\mathrm{P}$ and $\mathrm{K}$ contents generally increased linearly as $\mathrm{K}$ levels increased (Table 6). This response occurred because greater HA was associated with increased K level. Potassium accumulation in aboveground tissue observed in the current study was smaller than in most reports for bermudagrass.

\section{Selected Soil Chemical Properties}

Fertilization treatments showed no effect on soil $\mathrm{pH}$ and extractable $\mathrm{K}$ and $\mathrm{P}$ concentrations. At the end of the 3-yr study, soil $\mathrm{P}\left(15 \mathrm{mg} \mathrm{kg}^{-1}\right)$ and $\mathrm{K}\left(7 \mathrm{mg} \mathrm{kg}^{-1}\right)$ levels remained within the low range (Table 1$)$ for bermudagrass and limpograss, suggesting that plant uptake and leaching provided heavy demands on K supply. Results observed in the current study are in agreement with Adjei et al. (2001), who observed no increases in soil $\mathrm{K}$ or $\mathrm{P}$ levels in response to fertilization levels similar to those in the current study. Haby et al. (2007) reported no effect of fertilization on soil properties when $\mathrm{K}$ was applied at annual levels $<125 \mathrm{~kg} \mathrm{~K} \mathrm{ha}^{-1}$; however, these authors observed a linear increase in soil $\mathrm{K}$ test as $\mathrm{K}$ fertilization levels increased to 250 or $373 \mathrm{~kg} \mathrm{~K} \mathrm{ha}^{-1}$. Miller and Dickens (1996) also observed linear increases in extractable soil $\mathrm{K}$ (from 20 to $204 \mathrm{~kg} \mathrm{~K} \mathrm{ha}^{-1}$ in a loamy sand and from 12 to $193 \mathrm{~kg} \mathrm{~K} \mathrm{ha}^{-1}$ in a sand-peat medium) as $\mathrm{K}$ levels increased from 0 to $390 \mathrm{~kg} \mathrm{~K} \mathrm{ha}^{-1}$. Soil $\mathrm{K}$ concentrations were below the recommended level of $30 \mathrm{mg} \mathrm{K}$ 
$\mathrm{kg}^{-1}$ (Melich-1) suggested by Sartain (2002) for optimum bermudagrass growth. Despite the low soil P levels, no increase in bermudagrass or limpograss $\mathrm{HA}$ in response to $\mathrm{P}$ fertilization was observed during the 3 -yr study.

\section{SUMMARY AND CONCLUSIONS}

Potassium fertilization generally increased bermudagrass and limpograss HA linearly as $\mathrm{K}$ levels increased. However, bermudagrass HA observed in 2013 and 2014 was significantly less than that obtained in 2012, indicating that $\mathrm{K}$ fertilization levels evaluated in this study were insufficient to sustain the same level of HA and maintain the integrity of bermudagrass stands during the 3-yr study. The stand loss under limited levels of $\mathrm{K}$ fertilization should be considered in the economics and fertilization recommendations for bermudagrass. When bermudagrass is harvested multiple times per year, repeated applications of $\mathrm{N}$ and $\mathrm{K}$ will likely be required to optimize forage production, nutritive value, and stand persistence.

Compared with the data obtained in the first year of study, limpograss HA in 2014 was either the same (for treatments fertilized with $33 \mathrm{~kg} \mathrm{~K} \mathrm{ha}{ }^{-1}$ ) or increased (K level of $66 \mathrm{~kg} \mathrm{~K} \mathrm{ha}^{-1}$ ). Limpograss stand loss only occurred in the treatments receiving no $\mathrm{K}$. These data imply that limpograss requires smaller $\mathrm{K}$ fertilization levels than those required by Jiggs bermudagrass. No effect of $\mathrm{P}$ fertilization was observed on bermudagrass or limpograss responses, indicating that adequate levels of forage production can be obtained without additional $\mathrm{P}$ fertilizer inputs. Potassium and $\mathrm{P}$ fertilization showed no effect on soil $\mathrm{pH}$ and extractable $\mathrm{P}$ and $\mathrm{K}$ concentrations. Our data indicated that continuous aboveground removal without proper $\mathrm{K}$ fertilization resulted in poor bermudagrass and limpograss performance and concomitant stand loss. Adequate $\mathrm{K}$ supply is essential to sustain bermudagrass and limpograss productivity and longterm persistence.

\section{Conflict of Interest}

The authors declare that there is no conflict of interest.

\section{References}

Adams, W.E., and M. Twersky. 1960. Effect of soil fertility on winter killing of Coastal bermudagrass. Agron. J. 52:325326. doi:10.2134/agronj1960.00021962005200060007x

Adjei, M.B., C.S. Gardner, D. Mayo, T. Seawright, and E. Jennings. 2000. Fertilizer treatment effects on forage yield and quality of tropical pasture grasses. Proc. Soil Crop Sci. Soc. Fla. 59:32-37.

Adjei, M.B., R.S. Kalmbacher, and J.E. Rechcigl. 2001. Effect of $\mathrm{P}$ and $\mathrm{K}$ fertilizer on forage yield and nutritive value of Floralta limpograss. Proc. Soil Crop Sci. Soc. Fla. 60:9-14.

Adjei, M.B., J.E. Rechcigl, and R.S. Kalmbacher. 1998. Fertilization effects on the yield and chemical composition of limpograss pasture. Proc. Soil Crop Sci. Soc. Fla. 57:67-73.
Aguiar, A.D., J.M.B. Vendramini, J.D. Arthington, L.E. Sollenberger, J.M.D. Sanchez, W.L. da Silva et al. 2014. Stocking rate effects on 'Jiggs' bermudagrass pastures grazed by heifers receiving supplementation. Crop Sci. 54:2872-2879. doi:10.2135/cropsci2014.02.0135

Anderson, W., M.B. Parker, J.E. Knoll, and R.C. Lacy. 2016. Fertilization ratios of $\mathrm{N}-\mathrm{P}_{2} \mathrm{O}_{5}-\mathrm{K}_{2} \mathrm{O}$ for Tifton 85 bermudagrass on two coastal plain soils. 2016. Agron. J. 108:1542-1551. doi:10.2134/agronj2015.0585

Burton, G.W., R.N. Gates, and G.J. Gascho. 1997. Response of Pensacola bahiagrass to rates of nitrogen, phosphorus and potassium fertilizers. Proc. Soil Crop Sci. Soc. Fla. 56:31-35.

Burton, G.W., and W.W. Hanna. 1995. Bermudagrass. In: R.F. Barnes, D.A. Miller, and C.J. Nelson, editors, Forages, the science of grassland agriculture. 5th ed. Iowa State Univ. Press, Ames, IA. p. 421-429.

Coleman, S.W., J.E. Moore, and J.R. Wilson. 2004. Quality and utilization. In: L.E. Moser, B.L. Burson, and L.E. Sollenberger, editors, Warm-season $\left(\mathrm{C}_{4}\right)$ grasses. Agron. Monog. 45. ASA, CSSA, SSSA, Madison, WI. p. 267-308.

da Silva, S.C., and D. Nascimento, Jr. 2007. Avancos na pesquisa com plantas forrageiras tropicais em pastagens: Caracteristicas morfosisiologicas e manejo de pastejo. (In Portuguese.) Rev. Bras. Zootec. 36:122-138. doi:10.1590/S151635982007001000014

da Silva, S.C., A.F. Sbrissia, and L.E.T. Pereira. 2015. Ecophysiology of $\mathrm{C}_{4}$ forage grasses: Understanding plant growth for optimising their use and management. Agriculture 5:598625. doi:10.3390/agriculture5030598

Erickson, J.E., J.L. Cisar, G.H. Snyder, and J.C. Volin. 2005. Phosphorus and potassium leaching under contrasting residential landscape models established on a sandy soil. Crop Sci. 45:546-552. doi:10.2135/cropsci2005.0546

Haby, V.A., W.M. Stewart, and A.T. Leonard. 2007. Tifton 85 bermudagrass response to potassium sources and sulfur. Better Crops Plant Food 91:3-5.

Jones, W.F., and V.H. Watson. 1991. Applied phosphorus and potassium effects on yield of dallisgrass bermudagrass pastures. J. Plant Nutr. 14:585-597. doi:10.1080/01904169109364226

Keisling, T.C., F.M. Rouquette, Jr., and J.E. Matocha. 1979. Potassium fertilization influence on Coastal bermudagrass rhizomes and stands. Agron. J. 71:892-894. doi:10.2134/agro nj1979.00021962007100050044x

Kering, M.K., J. Guretzky, E. Funderburg, and J. Mosali. 2011. Effect of nitrogen fertilizer rate and harvest season on forage yield, quality, and macronutrient concentrations in Midland bermudagrass. Commun. Soil Sci. Plant Anal. 42:1958-1971. doi:10.1080/00103624.2011.591470

McKenzie, H.A., and H.S. Wallace. 1954. The Kjeldahl determination of nitrogen: A critical study of digestion conditionstemperature, catalyst, and oxidizing agent. Aust. J. Chem. 7:55-70. doi:10.1071/CH9540055

Mehlich, A. 1953. Determination of P, Ca, Mg, K, Na, and NH4. North Carolina Soil Test Division (Mimeo 1953). North Carolina Dep. of Agric., Raleigh, NC.

Miller, G.L., and R. Dickens. 1996. Bermudagrass carbohydrate levels as influenced by potassium fertilization and cultivar. Crop Sci. 36:1283-1289. doi:10.2135/cropsci1996.0011183X $003600050035 \mathrm{x}$

Moore, J.E., and G.O. Mott. 1974. Recovery of residual organic matter from in vitro digestion of forages. J. Dairy Sci. 57:1258-1259. doi:10.3168/jds.S0022-0302(74)85048-4 
Mylavarapu, R., D. Wright, and G. Kidder. 2013. UF/IFAS standardized fertilization recommendations for agronomic crops. Publ. SL-129. Coop. Ext. Serv., IFAS, Univ. of Florida, Gainesville, FL. http://edis.ifas.ufl.edu/ss163 (accessed 2 Mar. 2017).

Nelson, L.R., T.C. Keisling, and F.M. Rouquette, Jr. 1983. Potassium rates and sources for Coastal bermudagrass. Soil Sci. Soc. Am. J. 47:963-966. doi:10.2136/ sssaj1983.03615995004700050024x

Newman, Y.C., J.M. Vendramini, and A. Blount. 2011. Bahiagrass (Paspalum notatum): Overview and management. Publ. SSAGR-332. Coop. Ext. Serv., IFAS, Univ. of Florida, Gainesville, FL. http://edis.ifas.ufl.edu/ag342 (accessed 2 Mar. 2017).

Obour, A.K., M.L. Silveira, J.M.B. Vendramini, J.W. Jawitz, G.A. O'Connor, and L.E. Sollenberger. 2011a. A phosphorus budget for bahiagrass pastures growing on a typical Florida Spodosol. Agron. J. 103:611-616. doi:10.2134/agronj2010.0372

Obour, A.K., M.L. Silveira, J.M.B. Vendramini, L.E. Sollenberger, and G.A. O'Connor. 2011b. Fluctuating water table effect on phosphorus release and availability from a Florida Spodosol. Nutr. Cycling Agroecosyst. 91:207-217. doi:10.1007/s10705011-9456-y

Rechcigl, J.E., P. Mislevy, and H. Ibrikci. 1995. Response of established bahiagrass to broadcast lime and phosphorus. J. Prod. Agric. 8:249-253. doi:10.2134/jpa1995.0249

Rechcigl, J.E., G.G. Payne, A.B. Bottcher, and P.S. Porter. 1992. Reduced phosphorus application on bahiagrass and water quality. Agron. J. 84:463-468. doi:10.2134/agronj1992.0002 $1962008400030021 x$

Robinson, D.L. 1985. Potassium nutrition of forage grasses. In: R.D. Muson, editor, Potassium in agriculture. ASA, CSSA, SSSA, Madison, WI. p. 895-914.

Robinson, D.L. 1996. Fertilization and nutrient utilization in harvested forage systems: Southern forage crops. In: R.E. Joost and C.A. Roberts, editors, Nutrient cycling in forage systems. Proceedings of a Symposium, Columbia, MO. 7-8 Mar. 1996. Potash and Phosphate Inst. and Found. Agron. Res., Manhattan, KS. p. 65-92.

Sartain, J.B. 2002. Tifway bermudagrass response to potassium fertilization. Crop Sci. 42:507-512. doi:10.2135/cropsci2002.0507
SAS Institute. 1996. SAS/STAT guide for personal computers. Version 6. SAS Inst., Cary, NC.

Silveira, M.L., V.A. Haby, and A.T. Leonard. 2007. Response of Coastal bermudagrass yield and nutrient uptake efficiency to nitrogen sources. Agron. J. 99:707-714. doi:10.2134/ agronj2006.0200

Silveira, M.L., A.K. Obour, J.M.B. Vendramini, and L.E. Sollenberger. 2011. Using tissue analysis as a tool to predict bahiagrass phosphorus fertilization requirement. J. Plant Nutr. 34:2193-2205. doi:10.1080/01904167.2011.618578

Silveira, M.L., J.M.B. Vendramini, and E. Jennings. 2013. Potassium fertilization of bermudagrass pastures and hayfields. The Fla. Cattlemen Livest. J. 77:38-41.

Slaton, N.A., R.E. DeLong, C.G. Massey, B.R. Golden, and E.T. Maschmann. 2007. Bermudagrass forage response to potassium fertilization. In: N.A. Slaton, editor, Arkansas Agricultural Experiment Station research series Vol. 558. Arkansas Agric. Exp. Stn., Fayetteville, AK. p. 64-68.

Snyder, G.H., and J.L. Cisar. 2000. Nitrogen/potassium fertilization ratios for bermudagrass turf. Crop Sci. 40:1719-1723. doi:10.2135/cropsci2000.4061719x

Snyder, G.H., and A.E. Kretschmer. 1986. Effect of K fertilization on growth and $\mathrm{K}$ recovery of four tropical pasture grasses on a south Florida Spodosol. Proc. Soil Crop Sci. Soc. Fla. 45:75-80.

Tilley, J.M.A., and R.A. Terry. 1963. A two-stage technique for the in vitro digestion of forage crops. J. Br. Grassl. Soc. 18:104111. doi:10.1111/j.1365-2494.1963.tb00335.x

Turner, T.R., and N.W. Hummel, Jr. 1992. Nutritional requirements and fertilization. In: D.W. Waddington, R.N. Carrow, and R.C. Sheaman, editors, Turfgrass. Agron. Monogr. 32. ASA, CSSA, SSSA, Madison, WI. p. 385-439.

Vendramini, J.M.B., A.T. Adesogan, M.L. Silveira, L.E. Sollenberger, O.C. Queiroz, and W.E. Anderson. 2010. Nutritive value and fermentation parameters of warm-season grass silage. Prof. Anim. Sci. 26:193-200.

Wilkinson, S.R., and G.W. Langdale. 1974. Fertility needs of the warm-season grasses. In: D.A. Mays, editor, Forage fertilization. ASA, CSSA, and SSSA, Madison, WI. p. 119-145. 